\title{
Aktywna obserwacja raka gruczołu krokowego w oparciu o doniesienia z konferencji ESTRO nr 35 w Turynie.
}

\section{Active observation of prostate cancer based on reports from the ESTRO 35 conference in Turin}

\author{
Wojciech Burchardt ${ }^{1}$ \\ ${ }^{1}$ Zakład Brachyterapii z Izbą Przyjęć, Wielkopolskie Centrum Onkologii, Poznań, Polska
}

\section{Streszczenie}

Rak gruczołu krokowego (RGK) dotyczy coraz większej liczby mężczyzn w Polsce. Zwiększenie dostępności do badania stężenia antygenu sterczowego (PSA) i większa świadomość społeczeństwa doprowadziła do wykrywania choroby u pacjentów bezobjawowych we wczesnym stadium. Skutkiem wczesnego wykrycia RGK jest możliwość zastosowania wielu opcji terapeutycznych. Jednakże u części chorych z RGK wprowadzenie leczenia nie wydłuży życia i nie poprawi jego jakości, a nawet ją obniży ze względu na skutki uboczne. Grupa chorych o niskim zaawansowaniu największy zysk terapeutyczny odnosi z aktywnej obserwacji (AO).

$\mathrm{AO}$ to postępowanie oparte na monitorowaniu zaawansowania klinicznego, biochemicznego i histopatologicznego w celu uniknięcia leczenia lub jego odroczenia. Mimo wielu zalet i bezpieczeństwa, jest nadal bardzo rzadko stosowana w Polsce. Celem pracy jest przedstawienie doniesień z konferencji Europejskiego Towarzystwa Radioterapii Onkologicznej (ESTRO) w Turynie w 2016 roku na temat AO. W trakcie konferencji omówiono postępowanie AO z punktu widzenia patologa, radiologa i onkologa.

Podsumowując, AO jest postępowaniem bezpiecznym, obarczonym niskim ryzykiem skutków ubocznych,a także ekonomicznie uzasadnionym u dobrze dobranych chorych.

\footnotetext{
Abstract stage patients achieve the best therapeutic gain from active surveillance (AS).

Adres do korespondencji

Wojciech Burchardt

Zakład Brachyterapii z Izbą Przyjęć

Wielkopolskie Centrum Onkologii, ul. Garbary 15, 61-866 Poznań, Polska

Telefon. +48 618850817; Fax. +48 618850935

e-mail: wojciech.burchardt@wco.pl
}

Prostate cancer (PC) is increasingly prevalent in Polish men. Better availability of prostate-specific antigen (PSA) screening and higher public awareness have led to early detection of the disease in symptomless patients. Early detection of PC enables many therapeutic options. However, in some PC patients, treatment will not prolong survival nor improve the quality of life, or will even make it worse due to side effects. Low- 
AS is a procedure based on monitoring the clinical, biochemical and histopathological stage of the disease to avoid avoid or delay treatment. Despite many benefits and safety, that modality is still very rarely used in Poland. The aim of the study is to present reports on AS from the European Society for Radiotherapy and Oncology (ESTRO) conference, Turin 2016. During the conference, AS was discussed from the pathologist's, radiologist's and oncologist's perspective.

Concluding, AS is a safe procedure with low risk of side effects and it is also cost-effective in well selected patients.

Stowa kluczowe: rak gruczołu krokowego, aktywna obserwacja

Keywords: prostate cancer, active surveillance

\section{Wstęp}

Rak gruczołu krokowego (RGK) jest w USA i w Europie najczęściej rozpoznawanym nowotworem złośliwym $(1,2)$. W Polsce najczęstszym rakiem u mężczyzn jest rak płuca, a rak gruczołu krokowego jest drugim najczęstszym nowotworem rejestrowanym w Krajowym Rejestrze Nowotworów (3). Jego zachorowalność ciągle rośnie, co się wiąże z trendem obserwowanym w krajach Europy Zachodniej, lepszą wykrywalnością i wydłużeniem czasu życia w naszym kraju (rycina 1). RGK był drugą przyczyną zgonów z przyczyn onkologicznych w naszym kraju w $2010 \mathrm{r}$.

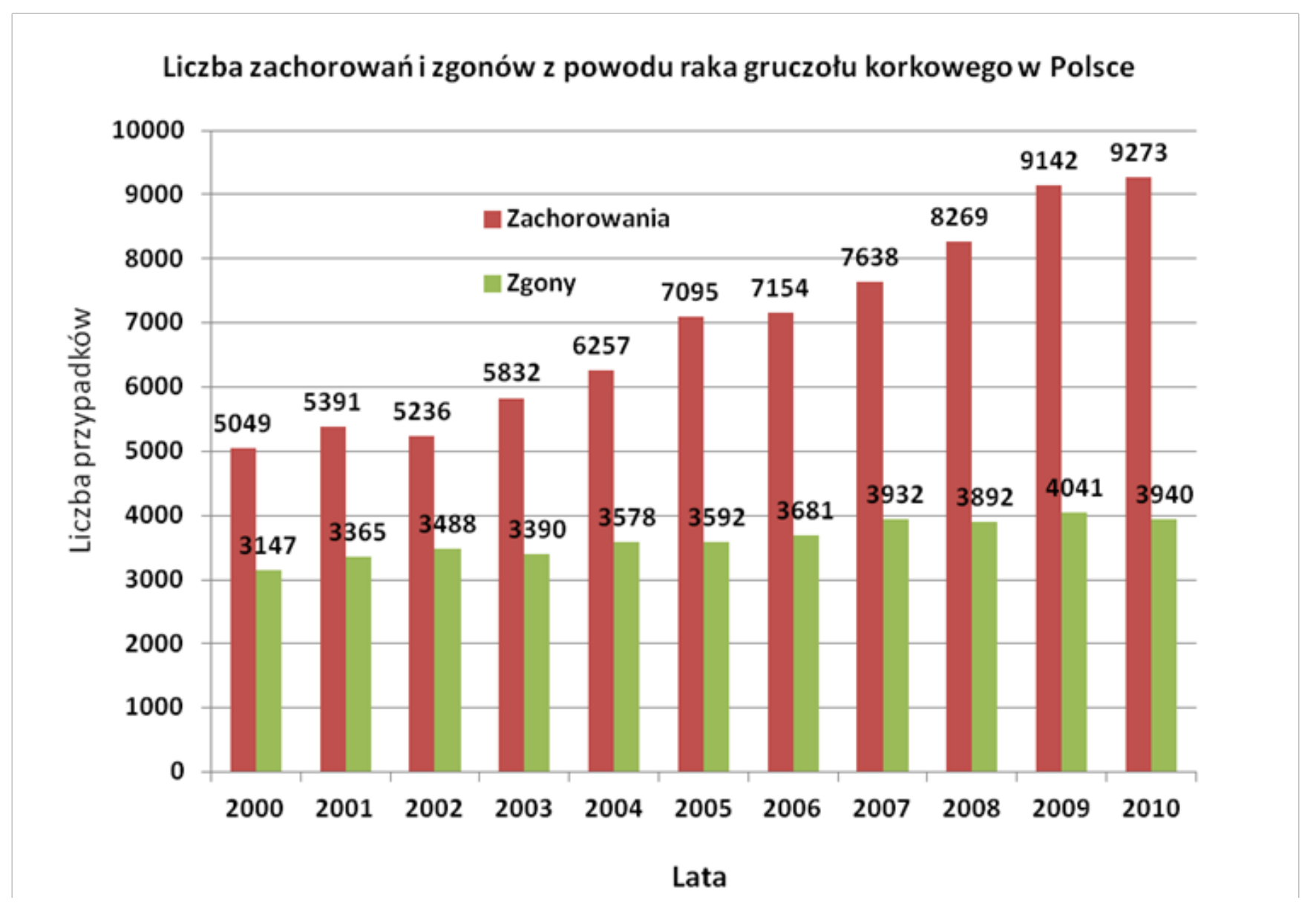

Rycina 1. Liczba zachorowań i zgonów z powodu raka prostaty w Polsce od 2000 -2010 roku na podstawie danych z Krajowego Rejestru Nowotworów (3). 
Umieralność z powodu tego nowotworu w Polsce wzrasta, ale w znacznie wolniejszym tempie niż zachorowalność, która uległa niemal podwojeniu od 1999 do 2010 roku (rycina 1). Oznacza to, że RGK dotyka coraz większej liczby osób i staje się epidemiologicznym wyzwaniem dla służby zdrowia w naszym kraju. Wczesne wykrycie raka stercza w stadium choroby ograniczonej do narządu jest możliwe dzięki coraz większej świadomości społecznej, a przede wszystkim dostępności do badania poziomu stężenia PSA w surowicy krwi.

Metoda leczenie pacjenta z RGK różni w zależności od zaawansowania choroby (grupy ryzyka) i prognozowanego przeżycia chorego. Przynależność do grupy ryzyka ustala się na podstawie zaawansowanie w skali TNM, wyniku badania patomorfologicznego z oceną w skali Gleason'a i wartością poziomu PSA przed leczeniem. Obecnie wyróżnia się 5 grup ryzyka według klasyfikacji National Comprehenisive Cancer Network (NCCN) z 2017 roku: bardzo niskiego, niskiego, pośredniego, wysokiego i bardzo wysokiego ryzyka wznowy nowotworu (4).

W grupie bardzo niskiego, niskiego oraz pośredniego ryzyka RKG zgodnie z zaleceniami zastosowanie ma wiele metod terapeutycznych $(3,5)$. Leczeniem może stanowić zabieg chirurgiczny, teleradioterapia, brachyterapia, aktywna obserwacja ( $\mathrm{AO}$ - z ang. active surveillance). U niektórych chorych baczna obserwacja (BO) jest zalecana, jeżeli przypuszczalny czas życia pacjenta wynosi mniej niż 10 lat. Powyższe postępowanie wynika z faktu, że u niektórych pacjentów z licznymi poważnymi chorobami towarzyszącymi leczenie raka prostaty może nie wypłynąć dodatnio na długość życia.

Na konferencji ESTRO w Turynie w 2016 roku całą sesję poświęcono postępowaniu metodą AO w ocenie patologa , radiologa oraz onkologa. Moim celem w tym doniesieniu jest przedstawienie cech wspólnych i różnic pomiędzy AO i BOoraz schematu ich prowadzenia u chorych z RGK, w oparciu o doniesienia na konferencji ESTRO 35 .

\section{Aktywna obserwacja}

RGK często postępuje bardzo wolno. Jest to związane z wolnym cyklem komórkowym RGK, a czas podwojenia tego nowotworu jest długi i waha się od 16 do 61 dni (6). Niektórzy pacjenci , a w szczególności starsi i obarczeni chorobami towarzyszącymi, mogą nigdy nie wymagać leczenia, a wyleczenie RGK nie wpłynie na ich długość życia. Jest to pojęcie RGK nieistotnego klinicznie (5). Leczeni RGK nieistotnego klinicznie może nie wydłużyć życia pacjenta, a jedynie narazić go na toksyczność przeprowadzonego leczenia. Pojęcie to dotyczy głównie chorych z bardzo niskiej (rysunek 2), niskiej i pośredniej grupy ryzyka (rysunek 3) wznowy według NCCN, u których można z powodzeniem zastosować AO lub BO (4).

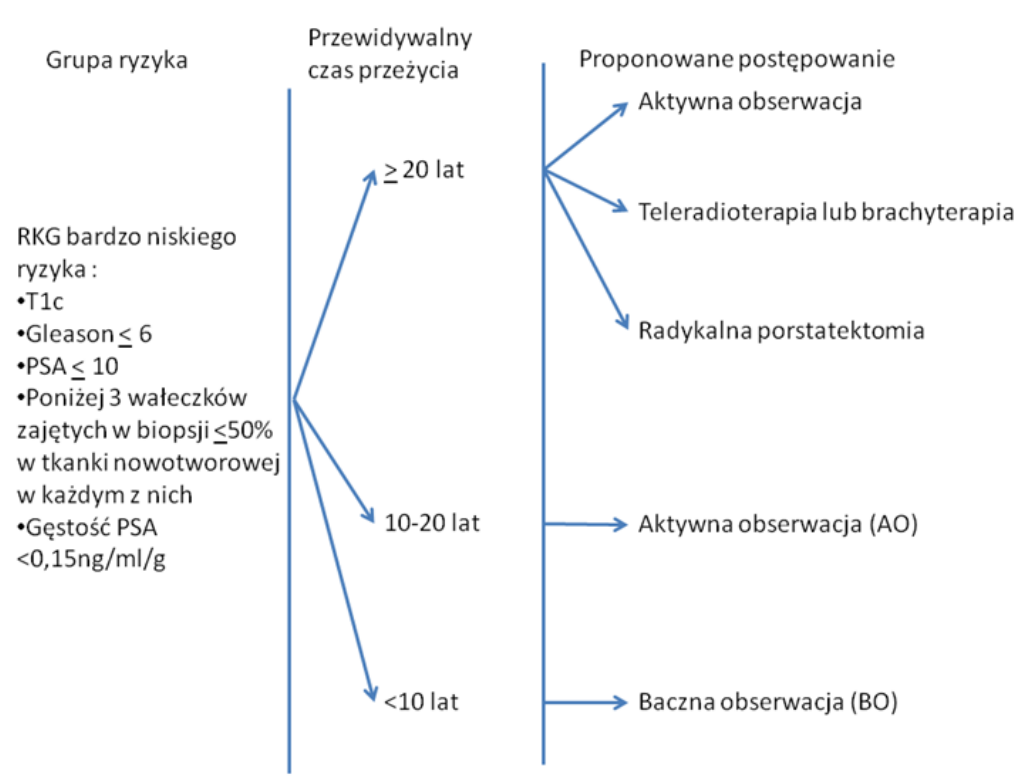

Rycina 2. Postępowanie u chorych z rakiem gruczołu krokowego(RGK) bardzo niskiego ryzyka w oparciu o amerykańskie rekomendacje National Comprehensive Cancer Network (4)
AO jest stosowana coraz częściej u chorych z RGK i zalecana w grupie niskiego i bardzo niskiego ryzyka z szacowanym czasem przeżycia powyżej 10 lat. Według schematu proponowanego przez amerykańskie towarzystwa polega na okresowym badaniu PSA ( nie częściej niż co 6 miesięcy), badaniu przezodbytniczym, biopsji powtarzanej co 12 miesięcy (tabela 2). Każde z powyższych badań może być przeprowadzone wcześniej, jeżeli zaistnieją objawy kliniczne. Wieloparametryczny rezonans magnetyczny (mpMR) prostaty można rozważyć, jeżeli pierwotnie zajęta była ściana przednia gruczołu krokowego, gdy istnieje podejrzenie bardziej agresywnej choroby lub gdy rośnie poziom stężenia PSA, a powtórne biopsje są negatywne (4). Momentem włączenia leczenia jest wzrost PSA w ok. $40 \%$ przypadków, wzrost zaawansowania 


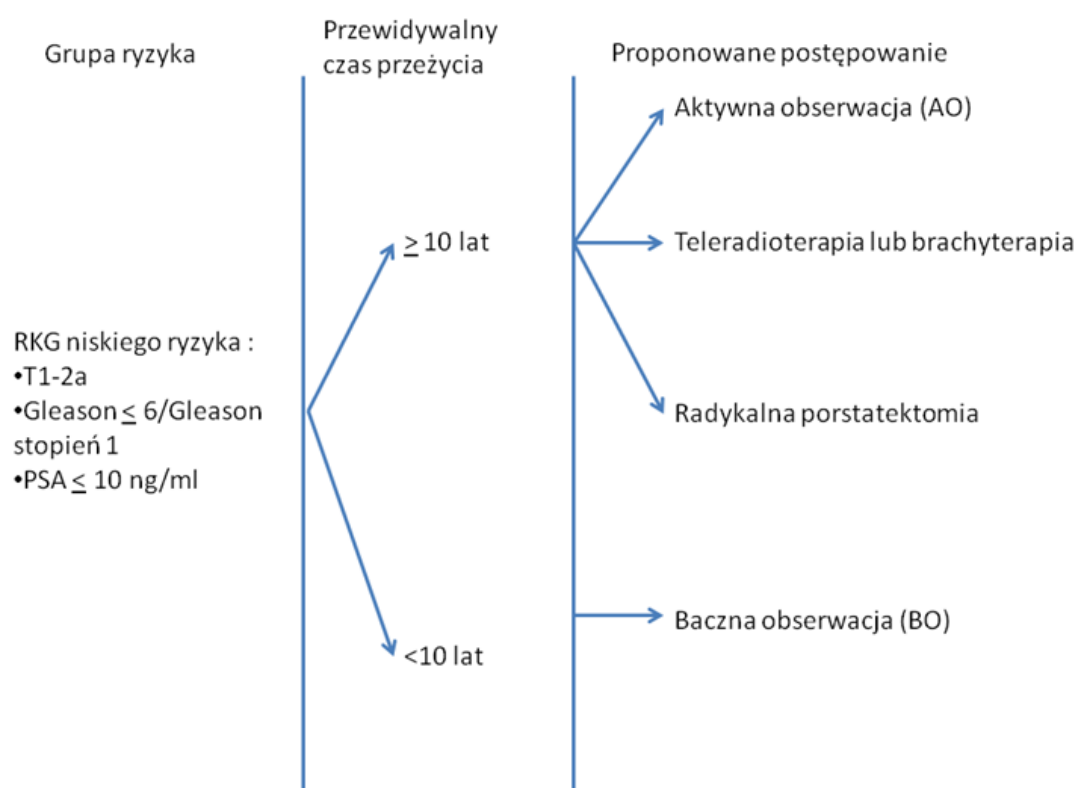

Rycina 2. Postępowanie u chorych $\mathrm{z}$ rakiem gruczołu krokowego(RGK) bardzo niskiego ryzyka w oparciu o amerykańskie rekomendacje National Comprehensive Cancer Network (4) histopatologicznego w ok. 40\%. W ok. 20 \% przypadków leczenie rozpoczęte jest mimo braku istotnego czynnika (tabela 2). Czynnikami niesklasyfikowanymi mogą być : brak chęci chorego do bycia poddanym AO lub progresja kliniczna w badaniu DRE lub mpMR. W grupie chorych zakwalifikowany do AO tylko 1/3 zostanie poddana leczeniu. Brak aktywnego leczenia chorego skutkuje uniknięciem działań niepożądanych takiego leczenia, w związku z czym jakość życia chorych będzie znacznie lepsza. Ryzyko leczenie raka nieistotnego klinicznie jest znacznie zmniejszone. Największą wadą AO jest ryzyko (niewielkie) utraty okazji wyleczenia pacjenta (okienka terapeutycznego). 1/3 osób otrzyma leczenie ze znacznym opóźnieniem , ale obecnie brak danych dowodzących, że takie postępowanie obniża wyleczalność. W trakcie AO konieczne są regularne biopsje prostaty, które są obarczone także pewnym ryzykiem skutków ubocznych (7).

Tabela 1. Porównanie bacznej obserwacji i aktywnej obserwacji w postępowaniu u chorych z rakiem gruczołu krokowego.

\begin{tabular}{|c|c|c|}
\hline & Baczna Obserwacja & Aktywna Obserwacja \\
\hline Cel & Uniknąć leczenia & Personalizacja leczenia \\
\hline Kryteria & $\begin{array}{c}\text { Szacowany krótki czas przeżycia/ } \\
\text { zaawansowana choroba }\end{array}$ & $\begin{array}{c}\text { Możliwe radykalne leczenie/ wczesne stadium } \\
\text { choroby }\end{array}$ \\
\hline Włącznie leczenie & Odroczone, gdy objawy & $\begin{array}{c}\text { Wczesne (wzrost: stopnia złośliwości w biopsji i/lub } \\
\text { PSA) }\end{array}$ \\
\hline Rodzaj leczenia & Paliatywne & Radykalne \\
\hline
\end{tabular}

\section{Baczna Obserwacja}

BO jest postępowaniem mało inwazyjnym i dość biernym w odróżnieniu do AO. Jest zalecaną opcją terapeutyczną u osób z RGK grupy niskiego i bardzo niskiego ryzyka, gdy szacowany czas przeżycia wynosi poniżej 10 lat (rycina 2 i 3). BO polega na badaniu PSA nie częściej niż co 6 miesięcy. Celem BO jest włącznie paliatywnej hormonoterapii, gdy wystąpią objawy miejscowe lub odległe (przerzuty) RGK. Wzrost PSA > 100 $\mathrm{ng} / \mathrm{ml}$ także powinien być momentem włączenia paliatywnej hormonoterapii (tabela 2). Największą zaletą BO jest możliwość uniknięcia efektów ubocznych niepotrzebnie wdrożonego leczenia, a także uniknięcie wczesnego włączenia leczenia hormonalnego lub bezzasadnej kontynuacji takiego leczenia. Dużą wadą takiego postępowania jest ryzyko zatrzymania moczu lub złamania patologicznego kręgosłupa w przebiegu RGK bez wcześniejszych objawów lub wzrostu PSA (4). 
Tabela 2. Porównanie schematów aktywnej obserwacji i bacznej obserwacji.

\begin{tabular}{|c|c|}
\hline Schemat aktywnej obserwacji & Schemat bacznej obserwacji. \\
\hline $\begin{array}{l}\text { - } \quad \text { Badanie PSA nie częściej niż } 6 \text { miesięcy } \\
\text { - } \quad \text { Badanie przez odbytnicze nie częściej niż co } \\
12 \text { miesięcy } \\
\text { Powtórne biopsje prostaty nie częściej } 12 \\
\text { miesięcy } \\
\text { - Wieloparametryczny rezonans magnetyczny } \\
\text { gdy naciek przedniej ściany gruczołu } \\
\text { korkowego lub/i podejrzenie progresji } \\
\text { choroby gdy rośnie PSA, a biopsje są } \\
\text { negatywne } \\
\text { Zastosowanie radykalnego leczenia gdy: } \\
\quad \text { W Wrost PSA } \\
\circ \quad \text { Wzrost złośliwości histopatologicznej } \\
\circ \quad \text { Progresja kliniczniczna }\end{array}$ & $\begin{array}{l}\text { - } \quad \text { badanie PSA nie częściej niż co } 6 \text { miesięcy } \\
\text { - zastosowanie paliatywnej hormonoterapii gdy: } \\
\quad \text { PSA > 100 ng/ml } \\
\circ \quad \text { objawy RGK (przerzuty, objawy miejscowe). }\end{array}$ \\
\hline
\end{tabular}

RGK - rak gruczołu krokowego

PSA - antygen sterczowy

\section{Spojrzenie Patologa}

W odniesieniu do AO nastąpiło wiele zmian wg oceny patologa. Najważniejsza zmiana dotyczy skali Gleason’a. Obecnie rozpoznanie RGK w skali Gleason’a 2-5 zniknęło z codziennej praktyki. Wynika to ze zmian w wprowadzonych na zjazdach Międzynarodowego Towarzystwa Patologów Urologicznych (ISUP) w latach 2005 i 2014 (8, 9). Dawniej część wyniku w skali Gleason'a 3 zawierała duże gruczoły durszlakowate - „cribirform” (obecnie jest to Gleason 4). Oznacza to, że dawniej Gleason $(3+3)$ zawierał $\mathrm{w}$ tej samej grupie chorych z dobrym rokowaniem i tych, którzy mieli w sobie komórki o potencjale przerzutowym . Obecnie chorzy z Gleason $(3+3)$ nie mają komórek zdolnych do dawania przerzutów (10). Skala oceny wyników patologicznych raka prostaty została zaktualizowana ponownie przez dr Jonathana Epsteina, który przeanalizował dane dotyczących 7869 chorych po radykalnej prostatektomii w szpitalu John's Hopkins (11). Jego sposób oceny wyników histopatologicznych został potwierdzony analizą na 20845 chorych z innych ośrodków akademickich (9). Epstein i wsp. oceniali ryzyko kontroli biochemicznej PSA po 5 latach od prostatektomii w skali 1-5 otrzymując odpowiednio wyniki 96\%, 88\%, 63\%, 48\%, 26\% (Tabela 3). Wyniki te zostały potwierdzone także dla próbek z biopsji prostaty przeprowadzonej przed radioterapią lub prostatektomią w Szwecji (National Prostate Cancer Registry Sweaden) (12). Powyższe zmiany zostały zaakceptowane przez Światową Organizację Zdrowia w raporcie o patologii i genetyce guzów męskiego układu moczowo-płciowego z 2016 roku (13).

Tabela 3. Skala histopatologiczna WHO w porównaniu do zmodyfikowanej skali Gleason, oraz wyniki po leczeniu radykalna prostatektomią.

\begin{tabular}{|c|c|c|c|}
\hline $\begin{array}{c}\text { Skala Epstein/WHO } \\
\mathbf{2 0 1 6}\end{array}$ & $\mathbf{5 y r B F F} \%$ & $\begin{array}{c}\text { Odpowiednik } \\
\text { w skali Gleason }\end{array}$ & Cech patologiczne \\
\hline 1 & $96 \%$ & $3+3=6$ & \begin{tabular}{c} 
Tylko pojedyncze dobrze wykształcone gruczoły \\
\hline 2
\end{tabular} \\
\hline $88 \%$ & $3+4=7$ & $\begin{array}{c}\text { Dominujący obraz dobrze wykształconych gruczołów } \\
\text { z niewielka ilości słabo wykształconych/zlewających się/ } \\
\text { durszlakowatych }\end{array}$ \\
\hline
\end{tabular}




\begin{tabular}{|c|c|c|c|}
\hline 3 & $63 \%$ & $4+3=7$ & $\begin{array}{c}\text { Dominujący obraz gruczołów z niewielka ilości słabo } \\
\text { wykształconych/zlewających się/ durszlakowatych } \\
\text { i niewielka dobrze wykształconych gruczołów }\end{array}$ \\
\hline 4 & $48 \%$ & 8 & $\begin{array}{c}\text { Tylko obraz gruczołów słabo wykształconych/ } \\
\text { zlewających się/ durszlakowatych lub } \\
\text { obraz brakujących gruczołów } \\
\text { z dobrze wykształconymi gruczołami }\end{array}$ \\
\hline 5 & $26 \%$ & $9-10$ & $\begin{array}{c}\text { Brak tworzenia gruczołów (martwica) z lub } \\
\text { bez słabo wykształconymi /zlewającymi się/ } \\
\text { durszlakowatymi gruczołami }\end{array}$ \\
\hline
\end{tabular}

WHO - World Health Organisation - Światowa Organizacja Zdrowia $5 \mathrm{yrBFF}-5$ years biochemical freedom from failure - 5 letnie kontrola biochemiczna po leczeniu radykalną prostatektomią

\section{Spojrzenie Radiologa}

Największe zastosowanie w postępowaniu metodą AO w badaniach obrazowych ma wieloparametryczna tomografia rezonansu magnetycznego (mpMR $\mathrm{z}$ ang multiparametric magnetic resonance imaging). MpMR daje możliwość wykrycia i monitorowania raka prostaty „in vivo” , podobnie jak biopsja (14). Obecnie główną rolą mpMR jest wykluczenie pacjentów z obserwacji metodą AO i zakwalifikowanie ich do innego leczenia. Zastosowanie mpMR jest szczególnie przydatne w przypadku, gdy pacjent z małym guzem o niskim stopniu złośliwości w rzeczywistości ma ognisko w wysokim stopniu złośliwości, które wykluczałoby go z AO. Takie ognisko można wykryć przy pomocy mpMR, a następnie pobrać wycinki za pomocą ultrasonografii przezodbytniczej (TRUS) lub fuzji TRUS z rezonansem magnetycznym (MR).

MpMR ma bardzo wysoką wartość predykcyjną ujemną, w szczególności dla raków z pośredniej i wysokiej grupy ryzyka. Podsumowując - brak obecności zmian złośliwych w mpMR oznacza, że brak jest klinicznie istotnego raka u badanego pacjenta. Ponadto $\mathrm{w}$ badaniu mpMR widząc ognisko możemy prognozować jego złośliwość $(15,16)$. MpMR jest używany do prognozowania skali Gleason’a główne przez ocenę dyfuzji i pozornego współczynnika dyfuzji (ADC ang. Apparent Diffusion Coefficient ). Występuje odwrotna proporcjonalność między ADC a skalą Gleason'a. Jeżeli obserwuje się znaczne osłabienie dyfuzji w badanym ognisku, a wyniki biopsji w skali Gleason'a wskazują na raka o niskim stopniu złośliwości - powinno się rozważyć powtórzenie biopsji.

Mimo bardzo dużych możliwości zastosowania mpMR w schematach AO, ta forma obrazowania nie pojawia się jako obowiązkowa w schemacie tego postępowaniu, a jedynie jako opcja (tabela 2). Wiąże się to $\mathrm{z}$ brakiem dużych randomizowanych badań, które potwierdziłyby zastosowanie mpMR w AO. Wstępne dane wskazują, że mpMR ma bardzo duży wkład w biopsje kierowaną prostaty, która może wpływać znacząco na wybór odpowiednich kandydatów do AO. Zastosowanie mpMR przed kwalifikacją do AO może wykluczyć z niej aż 29\% kandydatów (17). Konieczne są badania z dłuższym okresem obserwacji, aby jednoznacznie potwierdzić zastosowanie mpMR w postępowaniu AO.

\section{Spojrzenie Onkologa}

RGK jest chorobą o bardzo zróżnicowanym przebiegu i obrazie histopatologicznym. W odróżnieniu np. do raka piersi nie wprowadzono jeszcze do praktyki klinicznej podtypów molekularnych. Podtypy molekularne pozwoliłyby w lepszy sposób kwalifikować chorych do AO.

Obecnie stosowane w ocenie molekularnej RGK są głównie 4 testy: Oncotype DX, Genomic Prostate Score (GPS), Prolaris:Cell Cycle Progression (CCP), ProMark (tabela 4)

Test OncotpeDx: Genomic Prostate Score (Oncotype DX) bada ekspresję panelu 17 genów: 12 genów zaangażowanych w 4 różne szlaki związane z rozwojem nowotworu i 5 genów referencyjnych (tabela 4). Wynik ekspresji genów jest mierzony w skali od o-10o (18). Wynik testu odczytuje się łącznie z danymi klinicznymi, aby oszacować szanse na korzystny wyniki histopatologiczny po prostatektomii. W badaniu 
weryfikującym zastosowanie testu u 395 mężczyzn z rakiem niskiego i pośredniego ryzyka został on włączony jako przedoperacyjna ocena łącznie ze skalą CAPRA (z ang. Cancer of the Prostate Risk Assessment) i grupami ryzyka NCCN. W obu modelach, 20-jednostkowe zwiększenie wyniku wiązało się z niemal dwukrotnym wzrostem prawdopodobieństwa wystąpienia niekorzystnego wyniku histopatologicznego (19). Obecnie OncotypeDx jest oceniany u chorych w AO. W pracy Badani i wsp. wykazano wzrost o 10\% decyzji lekarzy o zastosowaniu AO u pacjentów, jeżeli uzyskano niski wynik testu Oncotype Dx (20).

Test Prolaris: postępu cyklu komórkowego (Polaris Cell Cycle Progression) ocenia proliferacje RGK przez ilościową ocenę 46 genów (31 genów cyklu komórkowego , 15 genów opiekuńczych). Wynik jest prezentowany w punktach <0, 0-1, 1-2, 2-3, >3 punktów (tabela 4). Test został oceniony u 349 mężczyzn. Podaje prawdopodobieństwa przeżycia 10 letniego - odpowiednio 19,3\%, 19,8\%, 21,1\%

48,2\% (21). W analizie wieloczynnikowej wynik test Prolaris CCP prognozował ryzyko śmierci z powodu RGK podobnie jak Gleason >7. U chorych z wynikiem w skali Gleason < 7 nie miał zdolności predykcyjnej. Podobnie jak w z testem OnocotypeDX GPS, wymaga dalszych badań.

Test ProMark bazuje na ilościowej reakcji immunohistochemicznej ekspresji białek. 12 białkowa matryca została utworzona po analizie próbek u chorych po prostatektomii z wysokim wynikiem w skali Gleason’a i z niskim wynikiem. (22). Wynik testu poniżej 0,33 dawał 90 \% czułość na korzystny wynik histopatologiczny, a wynik powyżej o,8 dawał $95 \%$ specyficzność wyniku niekorzystnego (tabela 4). W analizie wieloczynnikowej wzrost wyniku o 0,25 był połączony z ponad trzykrotnym wzrostem ryzyka na niekorzystny wynik badania histopatologicznego.

Obecnie zastosowanie badania molekularne w podejmowaniu decyzji terapeutycznej w RGK jest trudne, ponieważ pobierając wycinki pobiera się także zdrową tkankę, możliwe jest też ominięcie ogniska o wyższym stopniu złośliwości, co może fałszować wyniki. Ponadto testy molekularne w RGK są dość kosztowne, a ich znacznie w odniesieniu do badań obrazowych i laboratoryjnych nie zostało do końca udowodnione. Konieczne jest przeprowadzanie dalszych badań w celu określenia przydatności tych testów w AO.

Tabela 4. Skala histopatologiczna WHO w porównaniu do zmodyfikowanej skali Gleason, oraz wyniki po leczeniu radykalna prostatektomią.

\begin{tabular}{|c|c|c|c|}
\hline $\begin{array}{c}\text { Skala Epstein/WHO } \\
2016\end{array}$ & 5 уУBFF \% & $\begin{array}{c}\text { Odpowiednik } \\
\text { w skali Gleason }\end{array}$ & Cech patologiczne \\
\hline 1 & $96 \%$ & $3+3=6$ & Tylko pojedyncze dobrze wykształcone gruczoły \\
\hline 2 & $88 \%$ & $3+4=7$ & $\begin{array}{c}\text { Dominujący obraz dobrze wykształconych gruczołów } \\
\text { z niewielka ilości słabo wykształconych/zlewających się/ } \\
\text { durszlakowatych }\end{array}$ \\
\hline 3 & $63 \%$ & $4+3=7$ & $\begin{array}{l}\text { Dominujący obraz gruczołów z niewielka ilości słabo } \\
\text { wykształconych/zlewających się/ durszlakowatych } \\
\text { i niewielka dobrze wykształconych gruczołów }\end{array}$ \\
\hline 4 & $48 \%$ & 8 & $\begin{array}{c}\text { Tylko obraz gruczołów słabo wykształconych/ } \\
\text { zlewających się/ durszlakowatych lub } \\
\text { obraz brakujących gruczołów } \\
\text { z dobrze wykształconymi gruczołami }\end{array}$ \\
\hline 5 & $26 \%$ & $9-10$ & $\begin{array}{c}\text { Brak tworzenia gruczołów (martwica) z lub } \\
\text { bez słabo wykształconymi /zlewającymi się/ } \\
\text { durszlakowatymi gruczołami }\end{array}$ \\
\hline
\end{tabular}

WHO - World Health Organisation - Światowa Organizacja Zdrowia

$5 \mathrm{yrBFF}-5$ years biochemical freedom from failure - 5 letnie kontrola biochemiczna po leczeniu radykalną prostatektomią 


\section{Podsumowanie}

Ilość pacjentów podanych AO ciągle rośnie, gdyż jest to bezpieczna forma postępowania u chorych z RGK. AO minimalizuje ilość osób niepotrzebnie poddanych leczeniu, które nie odniosą z niego korzyści, a jedynie nabędą skutki uboczne (23). Mimo kryteriów doboru pacjentów i tak ponad 20 \% z nich zakwalifikowany do AO ma RGK, którego trzeba leczyć inną metodą. Z drugiej strony część osób , które nie spełniają kryteriów $\mathrm{AO}$, mają RGK, który jest nieistotny klinicznie. Istnieje wielka potrzeba wprowadzania bardziej dokładnych testów diagnostycznych i czynników prognostycznych, jak i predykcyjnych, np. molekularnych , które pozwolą wybrać chorych odpowiednich do leczenia i do AO.

W przedstawionym doniesieniu największe zmiany w diagnostyce RGK wystąpiły w ostatnich latach w ocenie histopatologicznej. W 2014 roku wprowadzono nową skalę stopni złośliwości histopatologicznej RGK w skali od 1 do 5 (tabela), która jest z pewnością znacznie łatwiejsza w interpretacji dla lekarza i pacjenta , niż obecnie stosowana skala Gleason'a z tradycyjnym wynikiem od 2 do 10. Ponadto w odniesieniu do AO bardzo istotne jest zalecenie raportowania w procentach od 1 do 50 \% obecności stopnia Gleason'a $4 \mathrm{w}$ wynikach histopatologicznych Gleason'a 7 (3+4). Mimo, że zastosowanie AO w grupie pośredniego ryzyka i wyższych grupach nie jest dobrze udokumentowane, zmiana ta pozwoli zróżnicować chorych z 1\% Gleason’a 4 do tych z $50 \%$.

Obecnie jesteśmy w krytycznym punkcie dla schematów postępowania AO, które mogą ulec zmianie. Wyraźny jest duży wpływ na dobór pacjentów zaawansowanych technologii takich jak mpMR i testów molekularnych. Badania te bez wątpienia będą pomagać w codziennej praktyce klinicznej w monitorowaniu i diagnostyce, jednakże brak jeszcze ostatecznych schematów ich zastosowania. Ponadto RGK coraz częściej jest diagnozowany przy użyciu biopsji z zastosowaniem fuzji TRUS i MR, a brakuje ostatecznych dowodów, czy taka diagnoza odpowiada stosowanym grupom ryzyka RGK np. NCCN.

Podsumowując - obecnie kandydaci do AO mogą być bezpiecznie prowadzeni bazując na omówionych czynnikach takich jak : grupa ryzyka, szacowana długość życia, stan ogólny i potencjalne skutki uboczne leczenia. Moment przerwania AO i rozpoczęcia leczenia powinien się opierać na głównie na wzroście PSA, zmianie zaawansowania histopatologicznego lub progresji klinicznej w badaniu DRE lub mpMR.

\section{Konflikt interesu / Conflict of interest}

Nie występuje / None

\section{Piśmiennictwo / References}

[1] Bracarda S, de Cobelli O, Greco C, Prayer-Galetti T, Valdagni R, Gatta G, et al. Cancer of the prostate. Critical reviews in oncology/hematology 2005 Dec;56(3):379-96.

[2] Jemal A, Siegel R, Xu J, Ward E. Cancer statistics, 2010. CA: a cancer journal for clinicians2010 SepOct;6o(5):277-300.

[3] Nowotworów ZEiP. Krajowy Rejestr Nowotworów - Raporty na podstawie danych Centrum Onkologii. Warszawa: Zakład Epidemiologii i Prewencji Nowotworów Centrum Onkologii w Warszawie; 2013 [updated 19-11-2010; cited 2013 16-11-2013]; Available from: http://85.128.14.124/krn/.

[4] Network NCC. NCCN Clincal Practice Guidelines in Oncolgy (NCCN Guidelines) Prostate Cancer 2017 21-02-2017;2017(21-08-2017).

[5] Krzakowski M, Warzocha K. Zalecenia postępowania diagnostyczno-terpeutycznego w nowotworach złośliwych 2013 rok. Onkologia w praktyce klinicznej 2013;9(supl. B).

[6] Haustermans KM, Hofland I, Van Poppel H, Oyen R, Van de Voorde W, Begg AC, et al. Cell kinetic measurements in prostate cancer. International journal of radiation oncology, biology, physics1997 Mar 15;37(5):1067-70.

[7] Andriole GL, Bostwick DG, Brawley OW, Gomella LG, Marberger M, Montorsi F, et al. Effect of dutasteride on the risk of prostate cancer. N Engl J Med2010 Apr 01;362(13):1192-202.

[8] Epstein JI, Allsbrook WC, Jr., Amin MB, Egevad LL. The 2005 International Society of Urological 
Pathology (ISUP) Consensus Conference on Gleason Grading of Prostatic Carcinoma. Am J Surg Pathol2005 Sep;29(9):1228-42.

[9] Epstein JI, Zelefsky MJ, Sjoberg DD, Nelson JB, Egevad L, Magi-Galluzzi C, et al. A Contemporary Prostate Cancer Grading System: A Validated Alternative to the Gleason Score. European urology2015 Mar;69(3):428-35.

[10] Ross HM, Kryvenko ON, Cowan JE, Simko JP, Wheeler TM, Epstein JI. Do adenocarcinomas of the prostate with Gleason score (GS) $</=6$ have the potential to metastasize to lymph nodes? Am J Surg Pathol2012 Sep;36(9):1346-52.

[11] Pierorazio PM, Walsh PC, Partin AW, Epstein JI. Prognostic Gleason grade grouping: data based on the modified Gleason scoring system. BJU international2013 May;111(5):753-60.

[12] Loeb S, Folkvaljon Y, Robinson D, Lissbrant IF, Egevad L, Stattin P. Evaluation of the 2015 Gleason Grade Groups in a Nationwide Population-based Cohort. European urology2015 Jun;69(6):1135-41.

[13] Humphrey PA, Moch H, Cubilla AL, Ulbright TM, Reuter VE. The 2016 WHO Classification of Tumours of the Urinary System and Male Genital Organs-Part B: Prostate and Bladder Tumours. European urology2016 Jul;70(1):106-19.

[14] Turkbey B, Brown AM, Sankineni S, Wood BJ, Pinto PA, Choyke PL. Multiparametric prostate magnetic resonance imaging in the evaluation of prostate cancer. CA: a cancer journal for clinicians2015 Jul;66(4):326-36.

[15] Panebianco V, Barchetti F, Sciarra A, Ciardi A, Indino EL, Papalia R, et al. Multiparametric magnetic resonance imaging vs. standard care in men being evaluated for prostate cancer: a randomized study. Urol Oncol2015 Jan;33(1):17 e1- e7.

[16] Siddiqui MM, Rais-Bahrami S, Turkbey B, George AK, Rothwax J, Shakir N, et al. Comparison of MR/ ultrasound fusion-guided biopsy with ultrasound-guided biopsy for the diagnosis of prostate cancer. JAMA2015 Jan 27;313(4):390-7.

[17] Stamatakis L, Siddiqui MM, Nix JW, Logan J, Rais-Bahrami S, Walton-Diaz A, et al. Accuracy of multiparametric magnetic resonance imaging in confirming eligibility for active surveillance for men with prostate cancer. Cancer2013 Sep 15;119(18):3359-66.

[18] Knezevic D, Goddard AD, Natraj N, Cherbavaz DB, Clark-Langone KM, Snable J, et al. Analytical validation of the Oncotype DX prostate cancer assay - a clinical RT-PCR assay optimized for prostate needle biopsies. BMC Genomics2013 Oct 08;14:690.

[19] Klein EA, Cooperberg MR, Magi-Galluzzi C, Simko JP, Falzarano SM, Maddala T, et al. A 17-gene assay to predict prostate cancer aggressiveness in the context of Gleason grade heterogeneity, tumor multifocality, and biopsy undersampling. European urology2014 Sep;66(3):550-60.

[20] Badani KK, Kemeter MJ, Febbo PG, Lawrence HJ, Denes BlS, Rothney MP, et al. The Impact of a Biopsy Based 17-Gene Genomic Prostate Score on Treatment Recommendations in Men with Newly Diagnosed Clinically Prostate Cancer Who are Candidates for Active Surveillance. Urology Practice2015 ;2(4):1819.

[21] Cuzick J, Berney DM, Fisher G, Mesher D, Moller H, Reid JE, et al. Prognostic value of a cell cycle progression signature for prostate cancer death in a conservatively managed needle biopsy cohort. Br $\mathrm{J}$ Cancer2012 Mar 13;106(6):1095-9.

[22] Shipitsin M, Small C, Giladi E, Siddiqui S, Choudhury S, Hussain S, et al. Automated quantitative multiplex immunofluorescence in situ imaging identifies phospho-S6 and phospho-PRAS40 as predictive protein biomarkers for prostate cancer lethality. Proteome Sci2014;12:40.

[23] Tosoian JJ, Carter HB, Lepor A, Loeb S. Active surveillance for prostate cancer: current evidence and contemporary state of practice. Nat Rev Urol2016 Apr;13(4):205-15. 
